and post-implant plasma ACTH levels were measured showed reduced levels. Normal levels were reached in four of the six in whom pituitary implantation was the sole treatment. The attainment of normal plasma ACTH levels (below $80 \mathrm{ng} / \mathrm{l}$ ) seems a desirable objective, but most patients who have had bilateral adrenalectomy for Cushing's disease and who do not have Nelson's syndrome do have raised levels despite adequate replacement therapy. ${ }^{20}$

The effect of the procedure seems to be long lasting: there were no subsequent relapses, and one patient (case 4) was still in clinical remission with normal plasma ACTH levels 13 years after the pituitary implant. There were few surgical or functional complications of the procedure. Pituitary implant thus compares favourably with the other procedures used for treating Nelson's syndrome.

This series was too small to show which type of radionuclide gave the best results. Each variety of pituitary implant used was followed with at least one good result. We no longer use a combination of ${ }^{90} \mathrm{Y}$ and ${ }^{198} \mathrm{Au}$ as it is technically difficult to insert accurately. Now we initially assess the size of the tumour with plain radiography, lateral hypocycloidal tomography, and air encephalography. In cases suitable for a pituitary implant ${ }^{9} \mathrm{Y}$ calculated to give a dose of 150000 rads to the gland periphery is used. If the dorsum sellae is severely eroded there would be inadequate landmarks for implantation; also extension of the subarachnoid space into the pituitary fossa would rule out a pituitary implant because of the danger of a CSF leak, and under these circumstances a transnasal hypophysectomy would be preferred. If the tumour has a large suprasellar extension ( $>8 \mathrm{~mm}$ on air encephalography) the patient would be referred for transfrontal craniotomy. In the event, only two patients were judged more suitable for open surgery.

Two out of four patients showed a clearly normal sella at adrenalectomy, thus showing that it is impossible to exclude the risk of Nelson's syndrome by radiological examination of the fossa. Indeed, one of these patients still had a normal sella at the time of diagnosis of Nelson's syndrome.

From the histopathological viewpoint the present series is the largest so far reported. Nelson et $a l^{2}$ noted that two of their patients had "chromophobe adenomas," a statement that can be interpreted in the light of our recent findings ${ }^{8}$ as meaning active poorly granulated ACTH-secreting tumours. Rivière et al ${ }^{21}$ reported a case of Nelson's syndrome with light and electron microscopy findings similar to those described here, but no other biopsies seem to have been reported. Mucoid ACTH-secreting pituitary adenomas are probably central to this syndrome, but the relation of their origin to any presumptive hypothalamic disturbance is still obscure.

We thank Professor Russell Fraser, under whose care many of these patients were initially, for his encouragement in the compilation of data; Miss Rosemary Arnot, of the hospital department of medical physics, for the dosimetry and planning of each procedure; Dr Lesley Rees, for the plasma ACTH assays; and Dr E Vogl, of Hoechst UK Ltd, for supplies of luteinising hormone-releasing hormone. GFJ gratefully acknowledges support from the Cancer Research Campaign.

\section{References}

${ }^{1}$ Nelson, D H, et al, New England fournal of Medicine, 1958, 259, 161.

2 Nelson, D H, et al, Annals of Internal Medicine, 1960, 52, 560.

3 Rovit, R L, and Duane, T D, American fournal of Medicine, 1969, 46, 416.

4 Salassa, R M, et al, fournal of Clinical Endocrinology and Metabolism, 1959, $19,1523$.

${ }^{5}$ Burke, C W, et al, Quarterly fournal of Medicine, 1973, 168, 693.

6 Joplin, G F, et al, Lancet, 1961, 2, 1277.

7 Rees, L H, et al, Endocrinology, 1971, 89, 254.

${ }^{8}$ Lewis, P D, and Van Noorden, S, Archives of Pathology, 1972, 94, 119.

9 Coons, A H, et al, fournal of Experimental Medicine, 1955, 102, 49.

10 Harsoulis, P, et al, British Medical fournal, 1973, 4, 326.

11 Cloutier, M D, et al, American fournal of Diseases of Children, 1966, 112, 596.

12 Schiller, K R F, Proceedings of the Royal Society of Medicine, 1959, 52, 48.

13 MacKenzie, A D, and McIntosh, H W, American Fournal of Surgery, 1965, $110,135$.

14 Welbourn, R B, et al, British fournal of Surgery, 1971, 58, 1.

15 Espinoza, A, et al, Acta Endocrinologica (Kфbenhavn), 1973, 34, Suppl 173, 34.

${ }^{16}$ Harrison, M T, et al, Proceedings of the Royal Society of Medicine, 1970, 63,224

17 Linfoot, J A, et al, Transactions of the American Clinical and Climatological Association, 1970, 81, 196.

18 Linfoot, J A, et al, Progress in Atomic Medicine, 1971, 3, 219.

19 Forrest, A P M, et al, Proceedings of the Royal Society of Medicine, 1970, 53, 616.

20 Besser, G M, Clinical Endocrinology, 1973, 2, 175

${ }^{21}$ Rivière, J, et al, Annales d'Endocrinologie, 1975, 36, 359.

\title{
Comparison of atenolol and propranolol during insulin-induced hypoglycaemia
}

\author{
S P DEACON, D BARNETT
}

British Medical fournal, 1976, 2, 272-273

\section{Summary}

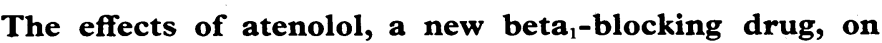
pulse rate, sweating, and blood glucose levels during insulin-induced hypoglycaemia were studied in a doubleblind crossover trial in eight normal subjects using placebo and propranolol as reference agents. The inten-

sity of induced hypoglycaemia was identical for atenolol, propranolol, and placebo. Propranolol prolonged hypoglycaemia, but atenolol did not. Atenolol may therefore. be safe for use in patients receiving insulin.

\section{Introduction}

The use of beta-blocking drugs in diabetic patients is contraindicated because they may intensify hypoglycaemia and prevent the adrenergic signs by which hypoglycaemia is recognised..$^{1-3}$ The new selective beta ${ }_{1}$-blockers, however, specifically antagonise the actions of catecholamines on the heart and may be free of hypoglycaemic side effects. Atenolol (Tenormin) is a recently developed cardioselective beta-blocker with a combination of pharmacological properties not shown by any other beta- 
blocker. ${ }^{4}$ This trial was designed to study the effects of atenolol during insulin-induced hypoglycaemia.

\section{Subjects and methods}

Eight subjects (seven men) aged 22-29 years were studied. All were healthy medical students taking no other medication. None were obese or suffered from respiratory disease. During the trial the subjects took their normal diet and avoided prolonged exercise. Three insulin tolerance tests were performed on each subject at seven-day intervals. Before each test the subjects took either: $(a)$ atenolol $50 \mathrm{mg}$ twice a day, (b) propranolol $80 \mathrm{mg}$ twice a day, or (c) placebo in a double-blind fashion using identical-looking tablets. These were taken for 48 hours with a final dose one hour before the beginning of the test. The subjects fasted overnight and then rested on couches. An indwelling intravenous cannula was inserted and a fasting blood sample taken. An intravenous dose of insulin was then given $(0 \cdot 1 \mathrm{U} / \mathrm{kg}$ body weight) and further blood samples taken at 30,60, 90, and 120 minutes. The pulse rates and degree of sweating (assessed on a scale 0-3) were noted at each of these times. The blood glucose levels were estimated using the GOD-Perid method (Boehringer pack).

\section{Results}

Effects on pulse rates and sweating-The resting pulse rates on atenolol and propranolol were similar and showed a decrease of about 12 beats/ min from the resting rate on placebo (table I). After hypoglycaemia had been induced the pulse rate in the placebo group rose by 11 beats/min and then returned to resting level by 120 minutes. All the values for the atenolol and propranolol groups were significantly different from those in the placebo group (table II), indicating effective beta-blockade. Pulse rates in the atenolol and propranolol groups were similar apart from the 30-minute value; by this time the atenolol group showed a mean rise in pulse rate of six beats $/ \mathrm{min}$. There was no difference in the degree of sweating between placebo, atenolol, or propranolol groups (table III), but the period of sweating was prolonged in the propranolol group.

TABLE I-Mean $(-S D)$ pulse rates (beats $/$ min)

\begin{tabular}{|c|c|c|c|c|c|}
\hline Time $(\min )$ : & 0 & 30 & 60 & 90 & 120 \\
\hline $\begin{array}{l}\text { Placebo } \\
\text { Atenolol } \\
\text { Propranolol }\end{array}$ & $\begin{array}{c}65-12 \cdot 7 \\
53 \cdot 9: 7 \cdot 1 \\
52 \cdot 5: 8 \cdot 7\end{array}$ & $\begin{array}{rl}76 & 10 \cdot 1 \\
59 \cdot 5 & 10 \cdot 6 \\
49 & 8 \cdot 5\end{array}$ & $\begin{array}{r:c}69 \cdot 5 & 9 \cdot 3 \\
53.6 & 6.9 \\
48.8 & 8.7\end{array}$ & $\begin{array}{c}69=9 \\
51 \cdot 9=7 \cdot 5 \\
49 \cdot 6=3 \cdot 4\end{array}$ & $\begin{array}{c:c}65 & 10 \cdot 1 \\
52 \cdot 3 & 6 \cdot 6 \\
47 \cdot 5 & 8 \cdot 2\end{array}$ \\
\hline
\end{tabular}

TABLE II-Significance ( $P$ values) of differences in pulse rates

\begin{tabular}{|c|c|c|c|c|c|}
\hline Time $(\min ):$ & 0 & 30 & 60 & 90 & 120 \\
\hline $\begin{array}{l}\text { Placebo } v \text { atenolol } \\
\text { Placebo } v \text { propranolol } \\
\text { Attenolol } v \text { propranolol }\end{array}$ & $\begin{array}{l}<0.05 \\
<0.05 \\
\text { NS }\end{array}$ & $\begin{array}{l}<0.01 \\
<0.001 \\
<0.05\end{array}$ & $\begin{array}{l}<0.01 \\
<0.001 \\
\text { NS }\end{array}$ & $\begin{array}{l}<0 \cdot 001 \\
<0 \cdot 001 \\
\text { NS }\end{array}$ & $\begin{array}{l}<0.01 \\
<0.01 \\
\text { NS }\end{array}$ \\
\hline
\end{tabular}

NS $=$ Not significant.

TABLE III-Sum of sweating scores*

\begin{tabular}{|c|c|c|c|c|c|}
\hline Time $(\min ):$ & 0 & 30 & 60 & 90 & 120 \\
\hline $\begin{array}{l}\text { Placebo } \\
\text { Atenolol } \\
\text { Propranolol }\end{array}$ & $\begin{array}{l}0 \\
0 \\
0\end{array}$ & $\begin{array}{l}7 \\
6 \\
9\end{array}$ & $\begin{array}{l}2 \\
3 \\
9\end{array}$ & $\begin{array}{l}0 \\
1 \\
5\end{array}$ & $\begin{array}{l}0 \\
0 \\
3\end{array}$ \\
\hline
\end{tabular}

Effects on blood glucose levels-There were no significant differences in the fasting blood glucose levels on placebo, atenolol, or propranolol. The degree of hypoglycaemia induced by equivalent doses of insulin was identical for all three groups (table IV) and represented a $68^{\circ}$ o fall in blood glucose (expressed as a percentage of the fasting blood glucose level). The rate of recovery of blood glucose levels was similar for placebo and atenolol, and both were significantly different from propranolol after 60 minutes: placebo $v$ propranolol at 90 and 120 minutes $\mathrm{P}<0.01$; atenolol $v$ propranolol at 90 and 120 minutes $P<0.05$. By 120 minutes the remaining blood glucose deficit for placebo was $8^{\circ}$, and for atenolol $12^{\circ}{ }_{0}$, whereas the deficit in the propranolol group was $31^{\circ} \mathrm{o}$

TABLE IV-Mean $( \pm S D)$ blood glucose levels ( $m$ mol $/$ l)

\begin{tabular}{|c|c|c|c|c|c|}
\hline Time $(\min ):$ & 0 & 30 & 60 & 90 & 120 \\
\hline $\begin{array}{l}\text { Placebo } \\
\text { Atenolol } \\
\text { Propranolol }\end{array}$ & $\begin{array}{l}4.14=0.43 \\
4.01=0.12 \\
3.98 \div 0.4\end{array}$ & $\begin{array}{r}1.31 \pm 0.49 \\
1.31 \pm 0.12 \\
1.3 \pm 0.57\end{array}$ & 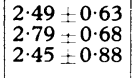 & $\begin{array}{c}3.35 \pm 0.63 \\
3.11 \pm 0.2 \\
2 \cdot 4: 0.75\end{array}$ & $\begin{array}{l}3.79 \pm 0.68 \\
3.55 \pm 0.18 \\
2.74 \pm 0.82\end{array}$ \\
\hline
\end{tabular}

Conversion: SI to traditional units-Glucose: $1 \mathrm{mmol} / 1 \approx 18 \mathrm{mg} / 100 \mathrm{ml}$.

\section{Discussion}

These results show that propranolol decreases the blood glucose recovery rate after insulin-induced hypoglycaemia and confirm the findings of Abramson et al. ${ }^{3}$ Atenolol, however, while providing effective beta-blockade, did not impair blood glucose recovery. This difference is most probably due to the highly selective action of atenolol, which produces only beta ${ }_{1}-$ adrenergic antagonism. Acute hypoglycaemia evokes the secretion of several hormones, including growth hormone, ${ }^{5}$ cortisol, ${ }^{6}$ adrenaline, and nor-adrenaline, ${ }^{7}$ which restore blood glucose levels to normal. The recovery of blood glucose levels is therefore due to several factors, the most important being hepatic glycogenolysis, but increased gluconeogenesis and decreased peripheral glucose uptake play a part. Adrenaline and noradrenaline are powerful stimulants of hepatic glycogenolysis ${ }^{8}$ by an action on presumed hepatic beta-adrenergic receptors. Non-selective beta-blockers such as propranolol might therefore be expected to prolong hypoglycaemia due to hepatic betaadrenergic blockade, but cardioselective drugs should be free of this side effect.

Many diabetic patients develop angina pectoris. Although beta-blockers have an established role in the management of angina, ${ }^{9}{ }^{10}$ their use in diabetic patients with angina is contraindicated. Nevertheless, beta-blockers are occasionally used with caution in diabetic patients with severe angina. This study and other current work ${ }^{11}$ suggests that cardioselective beta-blockers are preferable in such cases since they seem to be free of hypoglycaemic side effects.

Atenolol in doses of $50 \mathrm{mg}$ twice a day has been shown to be highly effective in managing severe angina ${ }^{12}$ as well as being remarkably free of troublesome side effects. ${ }^{13}{ }^{14}$ Further work is needed to establish the safe use of atenolol in insulin-dependent diabetics.

We thank Jill Unsworth for laboratory work, the West Riding Research Trust for financial support, and Imperial Chemical Industries, Pharmaceutical Division, Alderley Edge, Cheshire, for supplying the drugs.

\section{References}

${ }^{1}$ Kotler, M N, et al, Lancet, 1966, 2, 1389.

2 Wray, R, and Sutcliffe, S B J, British Medical fournal, 1972, 2, 592.

3 Abramson, E A, et al, Lancet, 1966, 2, 1386.

' Barrett, A M, et al, British fournal of Pharmacology, 1973, 48, 340.

${ }^{5}$ Roth, J, et al, Science, 1963, 140, 987.

${ }^{6}$ Landen, O J, et al, Fournal of Endocrinology, 1963, 27, 183.

: Goldfien, A, et al, fournal of Endocrinology, 1961, 21, 296.

8 Hagen, J H, and Hagen, P B, in Actions of Hormones on Molecular Processes, ed G Litwack, p 268. New York, Wiley, 1964.

9 Gillam, P M S, and Pritchard, B N C, American fournal of Cardiology, $1966,18,366$.

${ }_{10}$ Master, A M, and Jeffe, H L, American Heart fournal, 1974, 87, 321.

${ }^{11}$ Newman, R, personal communication.

12 Roy, P, et al, British Medical fournal, 1975, 3, 195.

${ }_{13}$ Hanson, L, et al, British Medical fournal, 1975, 2, 367.

11 Douglas-Jones, A P, and Cruickshank, J M, British Medical fournal, 1976, 2, 990. 